ISSN 1112-9867

Available online at http://www.jfas.info

\title{
IMPACT OF DIRECT SEEDING ON SOIL WATER RETENTION IN SEMI-ARID AREA (REGION HIGHLANDS OF WESTERN ALGERIA)
}

\author{
M. Kouadria ${ }^{* 1}$, A. Hassani ${ }^{1}$ D. Ghezali ${ }^{2}$, K. Oulbachir ${ }^{1}$ \\ ${ }^{1}$ Faculté des sciences de la nature et la vie, laboratoire d'agro biotechnologie et de nutrition en \\ zones semi-arides, Université Ibn Khaldoun Tiaret, Algérie \\ ${ }^{2}$ Ecole Nationale Supérieure d'Agronomie, El Harrach, Alger, Algérie
}

Received: 19 Mars 2017 / Accepted: 27 July 2017 / Published online: 01 September 2017

\begin{abstract}
This investigation is falls within the framework of conservation agriculture. Indeed, twentyfive years after the first of zero tillage farming experiences, this new method was named crop conservation agriculture because it helps preserve soil nutrients, water absorption enhancing and infiltration and biodiversity by maintaining the natural equilibrium in the soil. The objective of this is study is to compare the impact of the tillage (conventional work and the direct sowing) on water properties of the soil, especially the water-holding capacity of the soil in semi-arid zone (case of Tiaret region). According to the results, the comparative analysis between the two types of tillage (direct drilling sowing and conventional tillage) shows that water parameters studied such as moisture equivalent $(\mathrm{He})$, of holding capacity $(\mathrm{Cr})$, wilting point (Pf) and AWR (UK) are higher in the useful reserve case of direct seeding than in the case of conventional labor.
\end{abstract}

Keywords: Conservation agriculture, direct sowing, conventional labor, soil moisture, holding capacity.

Author Correspondence, e-mail: kouadria61@yahoo.fr

doi: http://dx.doi.org/10.4314/jfas.v9i3.15

\section{INTRODUCTION}

The direct seeding is a new mode of production whose main objectives are the conservation of natural resources including soil and water and efficient use. According to El Charras 
(2015), Conservation Agriculture is the set of agricultural practices aimed profitability and sustainability of agricultural activity and contribute to the environmental protection. The same author notes that Conservation Agriculture is based on improved natural functions of ecosystems, and thus an intensification of soil biological activity.

Boudiar (2013), noted that direct seeding allows restitution soil fertility and fight or controlled forms of erosion. At the environmental scale, AC (Conservation Agriculture) and TCS can reduce erosion by the presence of vegetation cover and absence or reduced tillage (Van Doran and Allmaras 1978; Unger et al., 1988).

According to Rieu (2001) and Young (2001), conservation agriculture, allows economically, reduced work times during crop establishment.

The reduction, therefore, input costs including energy and labor benefits are motivating the conversion of farmers to this system. Other advantages, such adaptation to climate changes that predict a narrowing of the rainy season and greater variability within and between annual, are obtained when adopting direct seeding.

According to Boudiar (2013), it would be interesting to develop in the southern and eastern Mediterranean, alternatives to current practices of dry-farming, deep plowing and work fallow, leading to numerous degradations, including organic carbon decline and soil fertility, soil loss by water and wind erosion that undermine agricultural systems. According to the same author, knowledge of hydric soil properties, especially the water retention capacity is a key input for sound water management, especially in semi-arid environment where the reduction of this resource is the first factor limiting agricultural production. Moreover, the practice of turning the soil before planting is so universal that it has been for centuries the symbol of agriculture. However, over the past 25 years, more and more farmers have abandoned their plows. The reason is that the modern plow is one of the root causes of land degradation.

In this context, the present work focuses on the study of direct seeding, which tends to limit the effects of tillage erosion and protect soil as a natural resource compared to other technical of plowing.

Our goal is to determine the influence of two farming techniques that are conventional tillage and no tillage or direct seeding on soil moisture, through the quantification of their effect on the water regime of the soil in rainfed grain: case a durum wheat crop.

\section{MATERIAL AND METHODS}

\subsection{Test schedule}


The field work was conducted during the 2012-2013 agricultural partner in the research station of the technical institute of field crops (ITGC), located at an altitude of $980 \mathrm{~m}$, a latitude of $35^{\circ} 24^{\prime} 8^{\prime \prime} \mathrm{N}$ and a longitude of $1^{\circ} 34^{\prime} 29 " \mathrm{E}$.

The soil used is clay loam texture. The study area is located in the bioclimatic 'semi-arid' by calculating the quotient of rainfall EMBERGER (Q) that depends on rainfall and temperatures specific to the Mediterranean climate by the equation

$Q=3.43 \times P / M-m(S t e w a r t, 1969)$

\subsection{The experimental set}

$10 \mathrm{~m}$

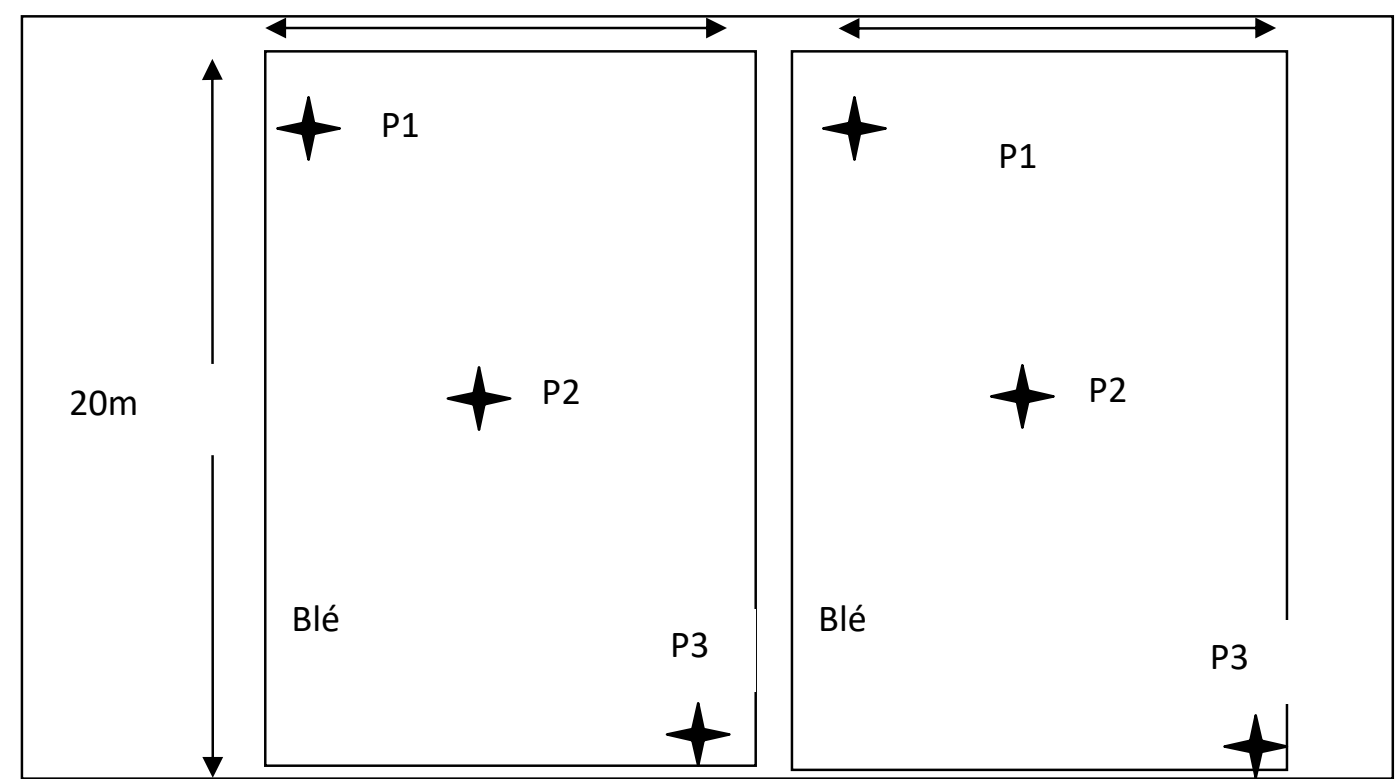

Fig.1. Plot size $(20 \mathrm{mx} 10 \mathrm{~m})$ and method of sample specimens (diagonal method)

The conventional tillage (CT) consists to plow (Mouldboard plow), to destroy the lumps (Cover Croop) to loosen the soil (Harrow) and sow (classical Row-seeder) (Table 01).

By against, the direct seeding (SD) consists of sowing directly in soil that is not working because only a small furrow opened with specially designed tools. The residue of the previous crop that protects and maintains the necessary moisture at planting (Carof, 2008) ensures ground cover. 
Table 01. Equipment used for the soil

\begin{tabular}{|l|c|c|}
\hline \multicolumn{1}{|c|}{ Ground work } & conventional tillage (CT) & \multicolumn{2}{c|}{ Direct seeding (SD) } \\
\hline Tillage (turning soil) & mouldboard plow & No \\
\hline $\begin{array}{l}\text { Plowing simulation } \\
\text { (destruction of clods) }\end{array}$ & Cover croop & No \\
\hline superficial ways (tilth) & Harrow & Drill-till \\
\hline \multicolumn{1}{|c|}{ Seedling } & classic Till Seed Drill & \\
\hline
\end{tabular}

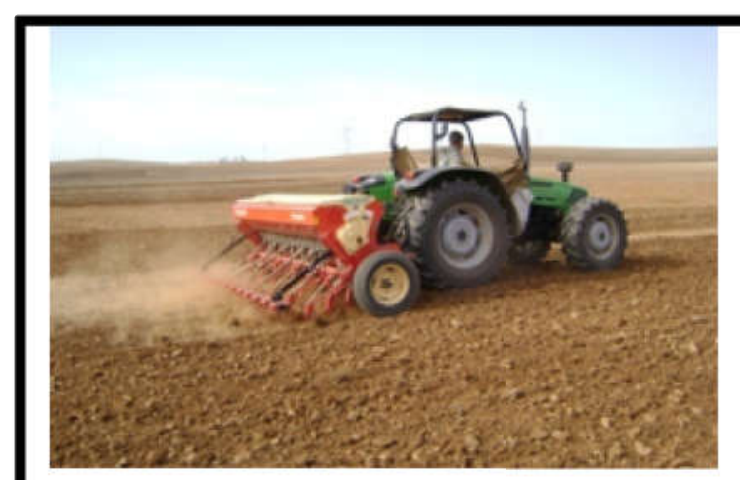

A-Classical seeder

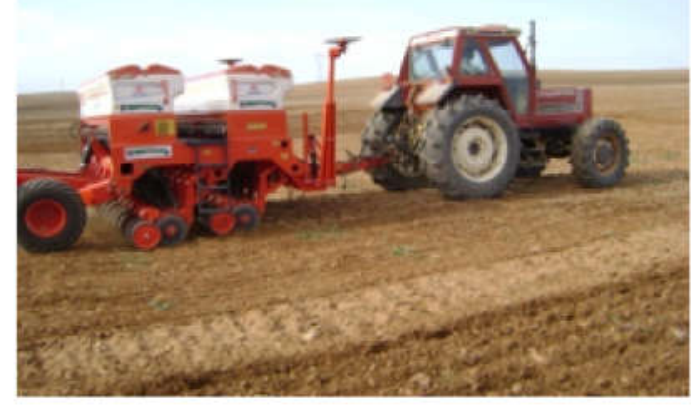

B- Direct seed drill

Fig.2. Technical plowing

\subsection{Measurement and analysis:}

\section{- Equivalent moisture measurement pf3}

Calculated by the formula $H E \%=\frac{A-B}{B-C} \times 100$
A: Tare of the box + earth after centrifugation
B: Tare of the box + earth dried at $105^{\circ} \mathrm{C}$
C: Tare of the box

- Measurement of retention capacity $\mathrm{Cr}(\% \mathrm{H} 2 \mathrm{O})=\mathrm{H} 2 \mathrm{O}$ retained in the soil with pf 2.5 . The determination of the retention capacity $(\mathrm{Cr})$ is a function of the moisture equivalent $(\mathrm{HE})$ and bulk density (da): $\mathrm{Cr}=\mathrm{HE} *$ da

- Measure the wilting point: $\operatorname{Pf}(\% \mathrm{H} 2 \mathrm{O})$ water retained in the soil with pf 4.2 according to the formula: $\mathrm{Pf}=\mathrm{HE} / 1.84$

The plant wilts and dies if moisture persists because Pf 4.2 is the permanent wilting point for most plants grown on soil.

- Water Measurement available for plants: This is the water capacity $($ EDP $(\%)=\mathrm{Cr}-\mathrm{Pf})$ 


\section{- Measurement of hydraulic conductivity (Ks):}

The principle consists of measuring the water filtration rate through a sample in a tube calibrated so to calculate the coefficient Ks. For each sample tested, 05 isolates taken from 10 $\mathrm{g}$ of ground tubes are used glass percolation of $3 \mathrm{~cm}$ diameter and $15 \mathrm{~cm}$ deep with a nylon canopy and $2 \mathrm{~cm}$ in height with a calibrated sand between 2 and $3 \mathrm{~mm}$ (Mathieu and Pieltain, 2003 in al Majou et al, 2007).

\section{RESULTS AND DISCUSSION}

\subsection{Results}

The figures 3 to 7 represent the results obtained concerning the various water parameters calculated during this study and which show the effect of the semi direct and semi conventional on these water parameters

\subsubsection{Moisture equivalent (\%): (He)}

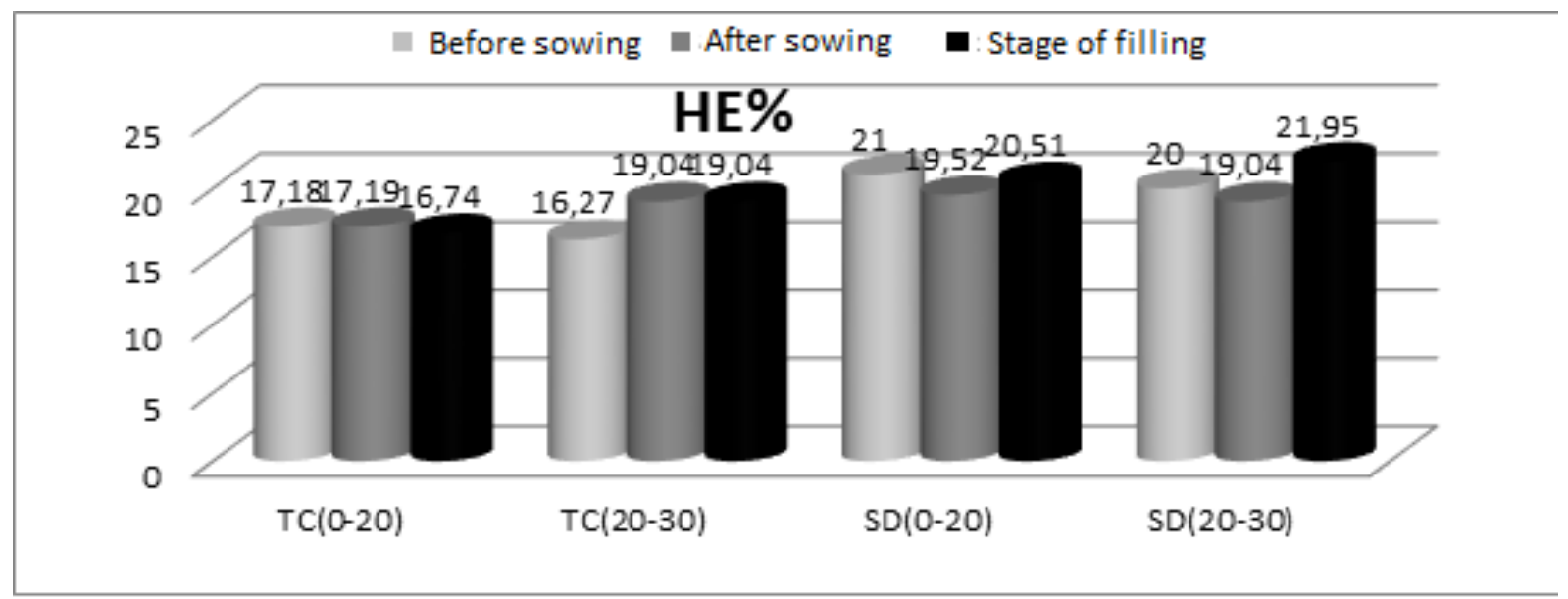

Fig.3. Variation of the equivalent soil moisture before sowing, after sowing and the filling stage for both farming techniques

According to Figure 3, we note that the equivalent humidity varies between $16.27 \%$ and $19.04 \%$ of the soil in the TC treatment. For against, in the SD treatment is higher and varies between $19.04 \%$ and $21 \%$ 


\subsubsection{The retention capacity $\mathrm{Cr}$}

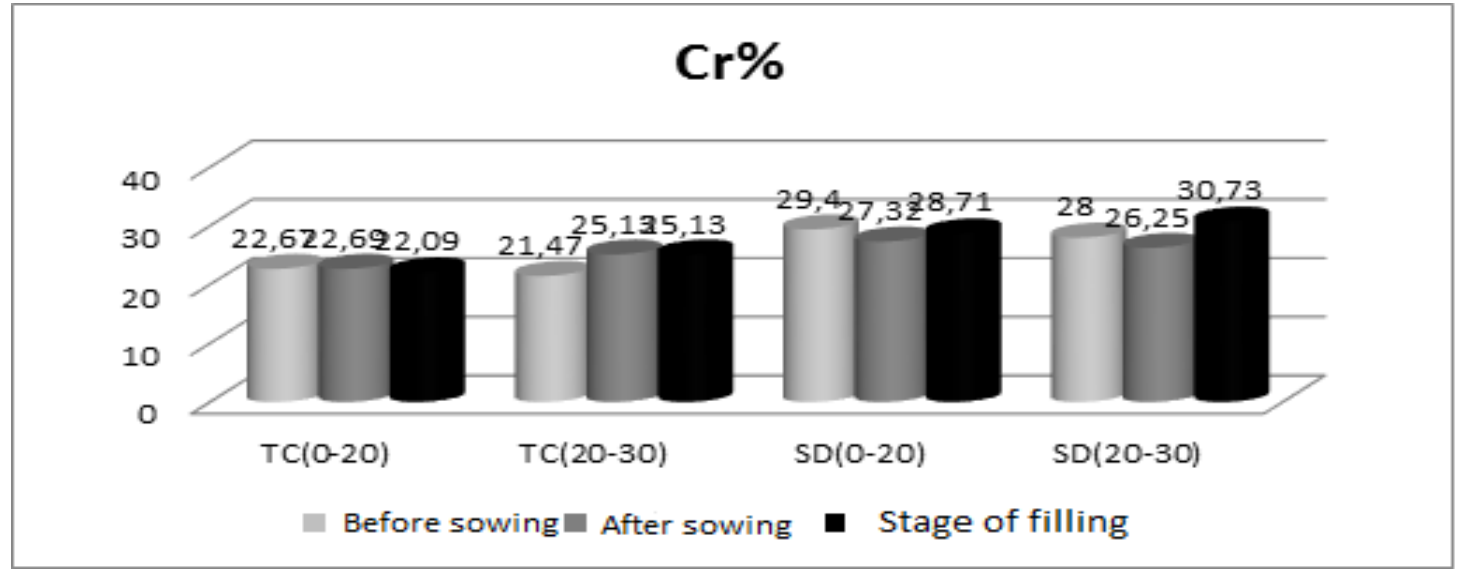

Fig.4. Change in holding capacity of soil $\mathrm{Cr}$ before sowing, after sowing and the filling stage for both farming techniques

We see from Figure 4 that the storage capacity varies depending on the type of work and its depth. Indeed, it is more important in no-till than in conventional work because in the SD treatment, soil structure is preserved following a single direct sowing pass. By cons, in the conventional work, the chain is complete and consequently, the structure loses its solid form which promotes evapo-transpiration

\subsubsection{The wilting point $P f$}

\section{$\mathrm{PF} \%$}

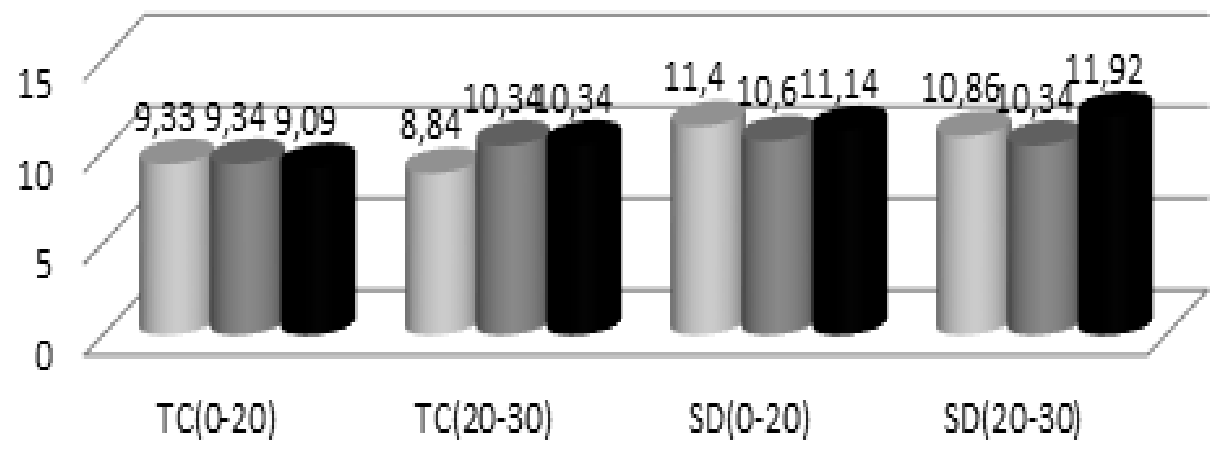

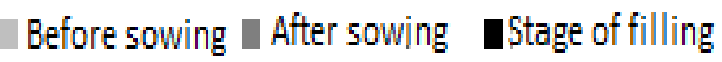

Fig.5. Change in wilting point PF ground before sowing, after sowing and the filling stage for both farming techniques 
According to the results (Figure 05), we find that the wilting point is significantly higher in no-till than in conventional tillage. However, it is almost constant throughout the stages of analysis.

\subsubsection{Water available for plants (EDP)}

The table below shows the availability of water at ground level before, after sowing, and at the filling stage.

Table 2. Evolution of water available to plants before sowing, after sowing and filling

\begin{tabular}{|c|c|c|c|c|}
\hline \multirow{2}{*}{$\mathrm{T}$} & \multirow{2}{*}{$\mathrm{P}(\mathrm{cm})$} & before sowing & after sowing & Stage of filling \\
\cline { 3 - 5 } & & $\mathrm{EDP} \%$ & $\mathrm{EDP} \%$ & EDP $\%$ \\
\hline $\mathrm{TC}$ & $(0-20)$ & 13.34 & 13.05 & 13 \\
\hline $\mathrm{TC}$ & $(20-30)$ & 13.41 & 14.79 & 14.79 \\
\hline $\mathrm{SD}$ & $(0-20)$ & 18 & 16.72 & 17.57 \\
\hline $\mathrm{SD}$ & $(20-30)$ & 17.14 & 16.31 & 18.81 \\
\hline
\end{tabular}

The results shown in this table 2, show that the amount of water stored at the two depths for the direct seeding (SD) is greater than in the case of the conventional tillage (CT).

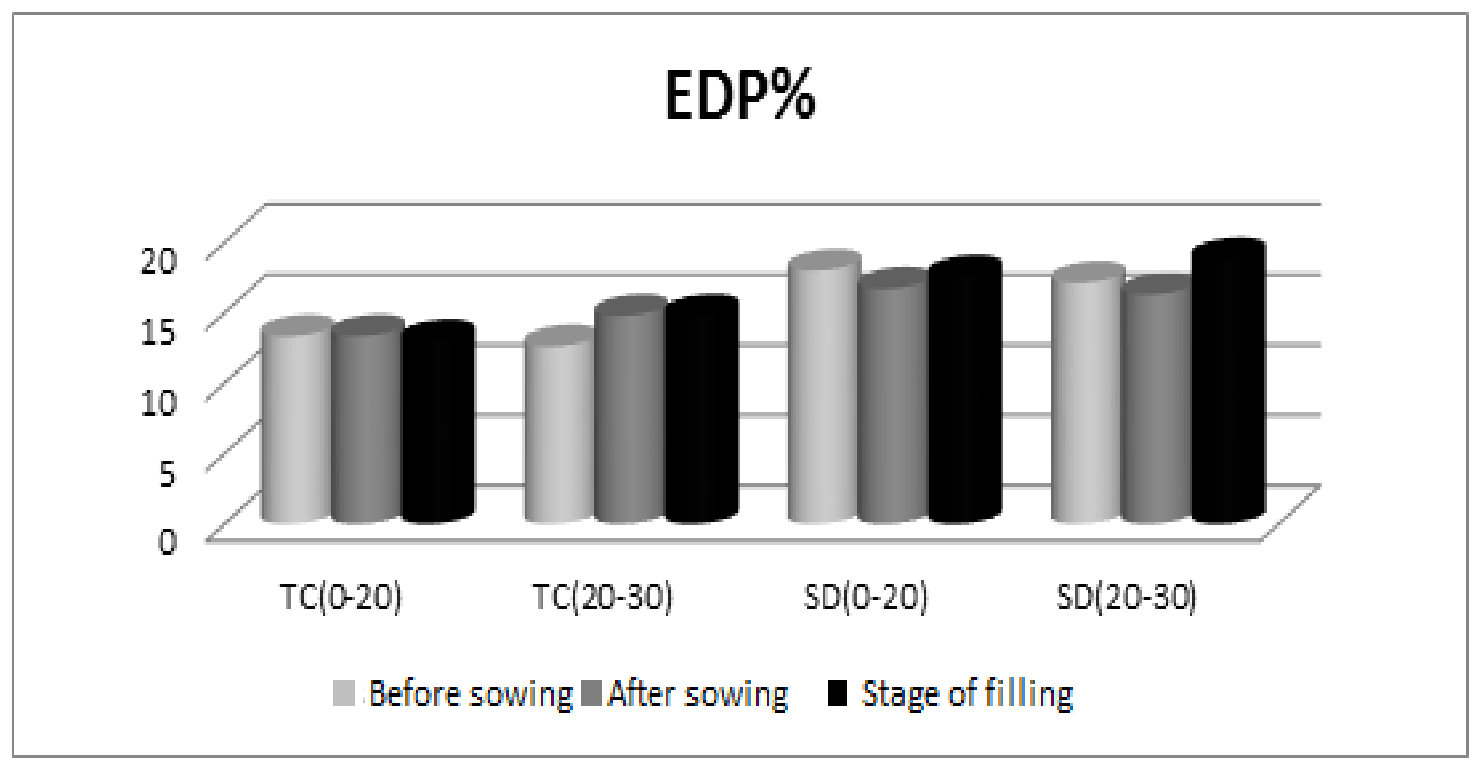

Fig.6. Change the water available to plants before sowing, after sowing and the filling stage for both farming techniques. 
The results obtained (Figure 06) show that the water available to plants is remarkably higher in the direct seeding than in conventional tillage. It is between 13 and 13.33 for the standard work $(0-20 \mathrm{~cm})$, and 17.14 to 18 for direct seeding $(0-20 \mathrm{~cm})$. This variation is due to rainfall waters.

\subsubsection{The hydraulic conductivity (Ks)}

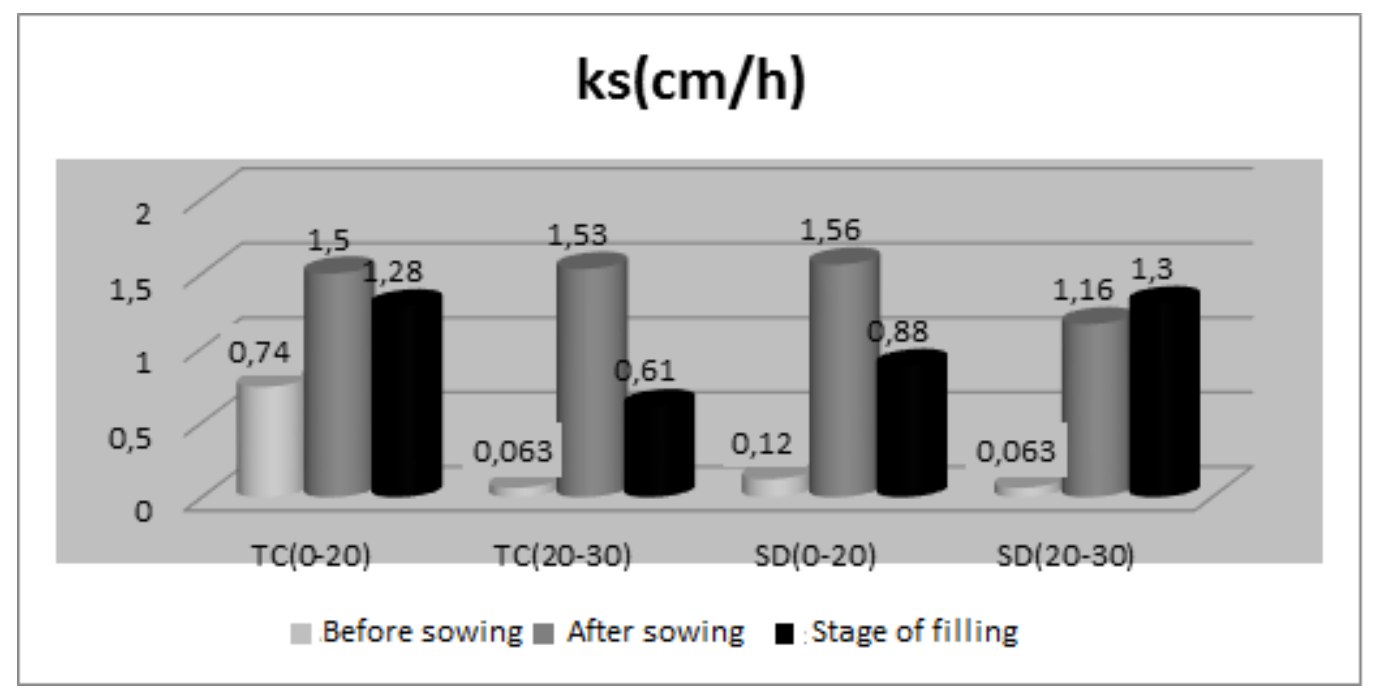

Fig.7. Change in soil hydraulic conductivity before sowing, after sowing and the filling stage for both farming techniques

Soil permeability is a very important physical parameter controlling the fertility of the soil. It follows from various characteristics such as soil type, structure and porosity.According to Figure 6, we see that the filtration coefficient varies according to the recommended cultivation technique. The highest rate is observed in the case of direct seeding (SD) with Ks $=1.56$. The rate of our soils is between 0.063 and $1.56 \mathrm{~cm} / \mathrm{h}$ and the filtration rate are low.

\section{DISCUSSION}

The water and air flow through a network of spaces between the soils particles. Thus, this network is composed of areas of macroporosity representing large spaces allowing a rapid flow of water and air. When the small spaces, according to Sasal et al, (2006), they form the microporosity. Moreover, this porosity is responsible for water retention is necessary for the plant to grow. (Left, 1968). The water content depends on the porosity and permeability of the soil. The permeability of the soil is defined by the infiltration rate of water $\mathrm{k}$ as measured by Darcy's law (Duchauffour, 2001). A layer of soil is deemed impervious to $\mathrm{k}$ values of the order of $10-9 \mathrm{~m} / \mathrm{s}$. Sandy soil (k between 5 and $10 \mathrm{~cm} / \mathrm{h}$ ) and a loam soil (k between 2 and $50 \mathrm{~cm} / \mathrm{h})$. 
According to the results recorded, we notice that the water content is relatively more important in direct seeding along the profile compared to conventional work.

Numerous studies show that unworked soil retains more water (water saving) due to the stabilization of pore space but also by the presence of the surface residues that reduce evaporation (Guérif 1994 in Carof, 2008).

The variability of this behavior is explained by the evolution of the pore network over time. However, pores are created after plowing that temporarily improves the infiltration rate of water, but the mechanical action of the plow and plow nickname tools can destroy the continuity of the pores formed during the previous crop cycle.

If aggregate stability increased in direct seeding no tillage leads, however, to decrease the porosity of the surface horizon against a conventionally tilled soil. Furthermore, Many studies carried out in various soil and climatic conditions conclude that an increase in the bulk density of the density in direct seeding within five to ten centimeters of soil (Basic et al, 2004) In this semi-arid area, the results for both conventional working methods and direct seeding for water reserve helpful when filling are respectively $13 \%$ and $17.57 \%$. These results prove that it is possible to significantly improve the level of productivity of cereals in different agro ecological regions by the method of direct seeding. Thus, we notice that the water content is relatively more important in direct seeding along the profile.

In addition, water retention properties of clayey soils in particular vary from floor to another according to the cation exchange capacity (CEC) related to the mass of clay, organization of elementary particles clay and the clay content. (Bruand and Tessier, 2000; Al Majou et al, 2007). Direct seeding, therefore, appears to be a conservative practice that limits damage caused by soil erosion, protects the water and its organic reserve. It is therefore recommended to practice this technique especially in semi-arid environments where rains are rare

According to Dupraz, (2006), the direct sowing technique allows seedlings to dry and thus take advantage of the first rains. Currently, the countries of Eastern Europe and the former Soviet Union states gradually appropriate the direct seeding technique to cope with a very short growing season due to long winters and harsh.

\section{CONCLUSION}

Agricultural production is the interaction of various factors and soil is a natural resource which constitutes the support of production systems. The soil management mode has as main purpose to provide the basic elements for plants for their development, such as air, water and nutrients. These components are sensitive to actions that are performed on the soil structure. 
This means that the aggregate arrangement of modifications alter soil porosity with effects on air and water flow. Thus, the adoption of Direct Seeding is done for economic reasons, but also agronomic climatic constraints. In semi-arid areas with very small and often poorly distributed rainfall, the Direct sowing technique allows seedlings to dry and thus take advantage of the first rains.

Considering the results obtained, this work shows that a simplification of tillage did not increase the yield of the crop, but reduces costs and preserves the soil.

It proves that it is possible to that significantly improve the level of productivity of cereals in different agro ecological regions by the method of direct seeding. Thus, we notice that the water content is relatively more important in direct seeding along the profile.

\section{ACKNOWLEDGMENTS}

We would like to thank the organizing committee of the second Forum on Biodiversity (Marrakech 27-29 / 03/2014) and in particular Pr. ELKHIATI N. and M. RAMDANI that allowed us to present the results of our work and the submit to criticism.

We are also very grateful to the leaders of the research stations of the great cultures of Tiaret (CETO and INRAA) and the University of Tiaret for the human, material and financial resources available to us.

The code and experimental data will be made available upon request to University of Tiaret (http://www.univ-tiaret.dz/?lang=2).

\section{REFERENCE}

Angers D.A. Samson N. et Legere A. 1993. Early changes in water-stable aggregation induced by rotation and tillage in a soil under barley production. Canadian Journal of Soil Science, 73, 51-59. doi.org/10.4141/cjss93-004

1. Balesdent, J., Chenu, C. \& Balabane, M. 2000.Relationship of soil organic matter dynamics to physical protection and tillage. Soil \& Tillage Research, 53, 215-230 doi.org/10.1016/S0167-1987(99)00107-5

2. Basic, F., Kisic, I., Mesic, M., Nestroy, O. \& Butorac, A. 2004. Tillage and crop management effects on soil erosion in central Croatia. Soil \& Tillage Research, 78, $197-$ 206. doi.org/10.1016/j.still.2004.02.001 
3. Boudiar Ridha, 2013 : Etude comparative des effets de travail du sol conventionnel et le semis direct sur l'evolution du sol en region semi-aride. Thèse de Magister. Université Ferhat Abbas Sétif 1 Faculté des Sciences de la Nature et de la vie.79p

4. Bruand A., Tessier D., 2000 - Water retention properties of the clay in soils developed on clayey sediments: significance of parent material and soil history. Eur. J. Soil Sci., 51, 679-688. prodinra.inra.fr/record/63188

5. Carof, M. 2008: Fonctionnement de peuplements en semis direct associant du blé tendre (Triticum aestivum L.) à différentes plantes de couverture; Thèse Doctorat INA, ParisGrignon .115p.

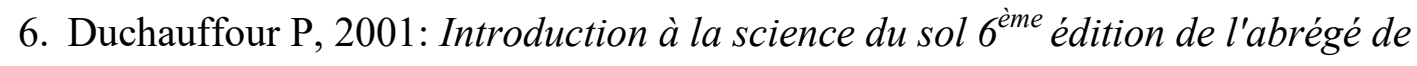
pédologie. Dunod. Ed. Masson. Paris. 314p.

7. Dupraz, C. 2006. Vers la gestion d'écosystèmes cultivés. In Club Déméter (ed.), 2006, Paris

8. F.A.O., 2005: Organisation des nations unis pour l'alimentation et l'agriculture.

9. Gaucher, G., 1968. Traité de pédologie agricole, Le sol et ses caractéristiques agronomiques, Dunod, Paris. 563 p.

10. Hassan Al Majou, Odile Duval, Olivier Josiere. 2007. Etude des propriétés de rétention en eau des sols argileux. 2007, Mulhouse, France. GFA, 2p., 2007, 18-19 avril 2007.

11. Hernánz J.L., Lopez R., Navarrete L. et Sánchez-Gíron V. 2002. Long-term effects of tillage systems and rotations on soil structural stability and organic carbon stratification in semiarid central Spain. Soil \& Tillage Research, 66, 129-141 doi.org/10.1016/S01671987(02)00021-1

12. Hireche A, 2007: Évolution de la pluviosité annuelle dans quelques stations arides algériennes. Sécheresse, 18 (4): 314-320 hdl:10670/1.0otp6o

13. O.N.S., 2011: Office national des statistiques.

14. Oussama El Gharras 2015 : Le Système du Semis Direct comme alternative pour l'adaptation aux Changements Climatiques dans les régions semi-arides du Maroc Séminaire de Clôture du projet ACLIMAS, Marrakech ; 1 Décembre 2015.

15. Saber N. et Mrabet R. 2002. Impact of no-tillage and trop sequence on selected soi1 quality attributes of a vertic calcixeroll soil in Morocco. Agronomie 22:451-459. doi.org/10.1051/agro:2002043

16. Rieu C., 2001. Les enjeux économiques de la simplification du travail du sol, Du labour au semis direct : enjeux Agronomiques, Conférence-débat INRA -ITCF, Salon International du Machinisme Agricole, pp 21-22 
17. Sasal, M. C., Andriulo, A. E. \& Taboada, M. A. 2006. Soil porosity characteristics and water movement under zero tillage in silty soils in Argentinian Pampas. Soil \& Tillage Research, 87, 9-18. doi.org/10.1016/j.still.2005.02.025

18. Stengel P., Douglas J.T., Guérif J., Goss M.J., Monnier G. et Cannell R.Q. 1984. Factors influencing the variation of some properties of soils in relation to their suitability for direct drilling. Soil \& Tillage Research, 4, 35-53. doi.org/10.1016/0167-1987(84)90015-1

19. Suwardji P. et Eberbach P.L. 1998. Seasonal changes of physical properties of an Oxic Paleustalf (Red Kandosol) after 16 years of direct drilling or conventional cultivation. Soil \& Tillage Research, 49, 65-77. doi.org/10.1016/S0167-1987(98)00149-4

20. Unger P.W., Langdale D.W. et Papendick R.I. 1988. Role of crop residues improving water conservation and use. Cropping strategies for efficient use of water and nitrogen, vol. 51 (ed. W. L. Hargrove), pp. 69- 100. Madison, WI:American Society of Agronomy 21. Van Doran J.R. et Allmaras R.R. 1978. Effect of residue management practices on soil physical environment, microclimate and plant growth. In Crop residue management systems (ed. W. R. Oschwald), ASA special publication 31, pp. 49-83.Madison,WI: American Society of Agronomy.

22. Young E. 2001. Charges de structures: les rouages de la mécanisation, Cultivar le Mensuel, ${ }^{\circ} 514$, septembre, p26-28

\section{How to cite this article:}

Kouadria M, Hassani A, Ghezali D, Oulbachir K.Impact of direct seeding on soil water retention in semi-arid area (region highlands of western algeria). J. Fundam. Appl. Sci., 2017, 9(3), 1485-1496. 